\title{
Women's Leadership in the Community Prismatic-Patriarch
}

\author{
Ashari Ismail* \\ Departmen of Sociology \\ Faculty of Social Science \\ Universitas Negeri Makassar \\ Makassar, Indonesia \\ ashariismail272@gmail.com
}

\author{
Firman Umar \\ Departmen Citizenship education \\ Faculty of Social Science \\ Universitas Negeri Makassar \\ Makassar, Indonesia \\ firman.umar@unm.ac.id
}

\begin{abstract}
This study is a study that seeks to review the use and the way of the prismatic community - patriarch, the study took the research settings in Manuba community, Barru Regency South Sulawesi. Along with the social change that entered rural, women's gait on the patriarch community began to shift, by placing women not only as "second class", working in the domestic, but could also be active in the public domain. This research, using theories: symbolical, feminism, patriarch, and Prismatic, uses a qualitative, comparative approach. The results of the research show social change, construction of the prismatic-patriarch community, looking at the male female there is no significant difference. Women can stand public, but at the same time, cannot leave the domestic realm. In this regard, the provision of women's places in the public domain is indicative of "female oppressive" as the head of the village, with the female head of the village chief, who can lift the country's secret comunitas.
\end{abstract}

Keywords: Leadership, women, community, prismatic, patriarch

\section{INTRODUCTION}

Women's leadership has long been a classic discourse, by feminists, on the equality of men and women. This mission has become an inseparable part of GAD [1]. Historically, women's leadership in Indonesia has been demonstrated by female leaders. Cut Nyadien, Raden Sartika, Raden Kartini and a number of other female figures. All have shown their gait --- as devotees, and fighters who are no less than men. The culture of marginalization, which is often attached to women in history, is undermined by the woman's gait in question, and is certainly a spirit for Indonesian women, to keep on fighting --- as part of community members who have bargaining positions [2], In development. The spirit --- the emancipation and equality of men's and women's rights, is the spirit of life, building an equal life, Without any marginalization in public life Such an announcement, is a necessary thing --- that every Indonesian woman needs to emulate.

Referring to the spirit shown by these historical figures, sociologically, one of the roles of women in terms of leadership is the work of women in the patriarchal prismastic community, in Manuba Village, Barru, South Sulawesi Province. The Head of Manuba Village, is a woman - who appears to be self-proclaimed, as part of Indonesian women, who have a leadership spirit - to construct themselves and the community to take part in developing the Manuba Village. In this connection, rural prismatic and patriarch Manuba, women ---, show that women are not second class creatures [3]. , but part of citizens who have independence --- who not only take part in the domestic sphere, but also in the public sphere. This phenomenon is a cultural derationalization, in the midst of a patriarchal culture which places women --- in domestic activities "under the iron fist" of men. How urgent this is, the following review shows.

\section{METHOD}

Research on female village headship leadership in the Manuba community, a patriarchal prismastic village, is an elementary research that tends to exclude how women appear as leaders in a society that tends to initially, deify men in the public sphere. In this connection, women are considered as a derationalization of male and female deferencing. The research method used is comparative qualitative, which is a method that seeks to compare a number of contemporary qualitative data by expressing the meaning contained in every action [4] of the actor who is the subject of research. The focus of the research seeks to examine the subjective reality that melakat on research actors, namely women village heads. Researchers are trying to look at research actors comprehensively, in order to uncover the meaning contained in each of the roles of the village head. In this connection, such an approach ... enables research to be carried out well, and to obtain research results in accordance with the objectives / objects of research. The author needs to point out that the focus of research, directed at subjective reality is a research focus that seeks to understand the research subject - through 
actions that are considered to contain various meanings in relation to research objectives. In this research, data collection is done by interviewing, observing and searching relevant libraries. The data used are secondary and primary data. After the data is collected, the next urgent urgency is to categorize the data. After categorized data, data analysis is performed, analysis is done by category analysis $[5][6][7][8]$

\section{RESULT AND DISCUSSION}

Manuba Community is a community located in Manuba Village, Mallusetasi District, Barru Regency, South Sulawesi, Indonesia. This community is located --- East of Mallusetasi District, which is still categorized as a transitional and patriarchal society. But apart from these cultural characteristics, this society has been contaminated with outside cultures. This society views, that not all external cultures have a negative side, there are cultures that contain cultural values (cognitive information and emotional ideas). [9] In other cases too, even though this society, still adheres to ancestral culture, they begin Many realize that there is an ancestral culture that must be abandoned, by making transformative changes [10]. Contamination with this outside culture, entered the Manuba community, through direct contact, or social media (television and mobile phones). Cultural filtering from the outside is done by customary arrangements and elders' advice (parents, religious leaders, and customs). Among the outside cultures that enter and influence the mindset of society are: equality or equality of humans (men, women). The difference in society in the view of the community is attention, and its power to the community.

At the same time, local culture that is considered outdated, abandoned like; placement of men, as "the main breadwinner, ruler of the tagga house, male tenancy", and various other patriarchal attributes, although still respecting men as heads of households, as part of culture --- local, which is believed in accordance with religious teachings. Likewise, the culture of ancestral siri and pace, respecting parents, loving children, is a local culture that is held in high esteem to be obeyed and inherited. In this connection, it is quite understood that the Manuba community, is a prismastic community, which on the side, still upholds local culture, but on the different side, foreign culture has been accepted, and seeks to adapt in social social life, in accordance with the demands of custom and religion they believe. In this case, there is an attitude of "ambiguity", in the social structure of society.

The impact of acceptance of outside cultures, but at the same time the Manuba community, perceiving gender differentiation (women-men), is something that must be accepted. Female men, are equal, and have the same social and cultural similarities in society. With a strong foothold on noble religious and customary values, the Manuba people understand that --- human beings are of the same level, as long as they uphold custom and religion, there is no difference between men and women. Men are muliah creatures because they are destined to lead in the household, and women are also muliah creatures because they are partners in leading households and have advantages in fostering households, and have also participated in making a real contribution in building a family economy. In this case, women are no longer understood as being mere recipients of income, but also able to provide for themselves and their families.

In the perception of the Manuba community, women can take part, not only in the domestic sphere, but also in the public, as long as it is attached to men. Women can be the main breadwinners, without leaving their profession as mothers of their children. Women are understood, can be household leaders and also community leaders. In connection with that some of the virtues held by women when given the mandate as a leader :. (1). Women have a high attitude of irrationality, so they are able to feel the state of the society they lead. In this case, arrogant attitude in developing positions is considered very far attached to women. (2). Women have innate, do not rush to make decisions, and even tend to be polite in providing solutions to social problems; (3). Women have authority that is able to undermine the patriarch attitude of men, which they lead. In other cases along with the advantages possessed by women in leading, at the same time men are considered to have a number of weaknesses, in leading, namely: (1). Men in leading, tend to be very rational in leading; and (2). Men tend to be superior and very patriarchal in protecting society.

They show the understanding of the Manuba community that they are elected by becoming a Village Head. Indeed, for some periods the community was led by men, only then was it led by a Village Head for Women. The choice of women in the Manuba community as village heads, it cannot be interpreted that women leave domestic work (washing, cooking, sweeping, breastfeeding, giving birth and various other domestic jobs), but rather shows that women can do public work, and no less than gait gait done by men. In line with this, it is quite announced, the views of the Manuba community that: it is not a contemptible job if women or men do household work. In this connection, some beliefs of the Manuba community, that it is not possible for a woman to leave domestic work. Domestic work does not have economic value, but it has an urgent impact on the sustainability of household productivity. This acknowledgment, is very well understood by the Manuba community in living their lives, along with the dynamics of change in the outside society, even though the Manuba people remain obedient to their ancestral heritage.

In relation to, the figure of the Village Head, as the subject of research, then in the view of the village head, domestic or household work should not be abandoned, 
because: (1). In the perception of the Manuba community, however and wherever women are, domestic duties must remain part of the routine that must not be abandoned; (2). The Manuba community, despite the patriarchal pattern, has gradually changed, but still places men as the head of the family, in the household, so that domestic tasks are still something that should not be abandoned by women, although not a few men also has also acted. (3). Vocational needs and demands, demanding women must take a dual role in domestic roles. In this connection it is quite understood that the leadership of women in the Manuba community is leadership that remains grounded in local culture, along with the changes that occur.

Women's leadership in the primitive patriarchal community, is research approached with a number of theories, namely symbolic, feminism, patriarch, and prismastic. In the view of symbolic theory, it is understood that the actor's behavior patterns are made possible by the meanings or meanings behind his actions. Paying close attention to symbolic theory --- then what is done by the woman Head of Manuba Village, is an action filled with meaning. The perceived meaning and meaning carried out by the village head woman, as an urgent actor in relation to the roles that are in society, which views that men and women are equal, there is no differentiation [9]. Likewise the meaning carried out in domestic roles, as well as in public roles. In this connection it is quite understood that the roles performed by women based on symbolic theory are roles --- accessing the meaning of an action or what is done by the village head woman, as human resources, in managing human natural [11]. In another case, related to the theory of femenism, the role of women is part of the women's movement [12][13] itself in expressing oneself, amid a patriarchal culture that curbs the actions of every woman. Femenismne is a movement of women, the gait of the female village head is --- the designation of the urgent roles of women in showing the true identity of humans as no less than men.

In terms of patriarchal theory, the condition of Manuba culture, or the surrounding Bugis community, is the condition of an area that has a culture that is still thick with patriarchal culture. In this connection what is done by the Manuba Village Head as a woman, is part of a shift in patriarch culture or the fading of patriarch values, even though respect for men as heads of households is maintained, due to religious values. The patriarchal theory, which tends to exploit women, is not indicated in the Manuba community, because of the shifting patriarchal values prevailing in society. In the case of primastic theory, it is understood that Manuba is a transitional, or transitional, area which is a condition in which the Manuba region, due to the current factor of change, allows this region to experience a cultural transition in every sector of life. Prismastic theory announces --- a social-cultural transition, allowing for a shift in society.

\section{CONCLUSION}

The leadership role of the Woman Head of Manuba Village, Mallusetasi Barru was a result of social change. The Manuba community was originally a community ---- that was patriarchal to the local culture they had, making this community thus put men as creatures who "tend to marginalize women". As changes occur, the Manuba community experiences a shift, Manuba grows into a prismastic, transition, and patriarchal culture experiences a shift. Women are no longer considered the second class of men, but humans who have positions that are equal to men. In this case, indicated by the election of women as --- Head of the Village.

\section{ACKNOWLEDGMENT}

This research, is part of a research conducted at the Manuba Community, South Sulawesi, Indonesia, entitled: WOMEN AND VILLAGE POLITICS A Study on Dedifferentiation and Derralization of the Role of Women in Village Heads in Rural Political Development, funded by DIPA Makassar State University

\section{REFERENCES}

[1] A. Ismail and F. Umar, "Perempuan dan Pembangunan Politik Kajian Tentang Profile dan Peran Politik Perempuan Kepala Desa dalam Pembangunan Demokratisasi Pedesaan," in Seminar Nasional LP2M UNM, 2019.

[2] M. Mustadjabar and A. Ismail, "Perempuan Migran dan Pelacur Terselubung (Kajian Tentang Faktor Penarik Terjadinya Prostittusi Terselubung di Kabupaten Wajo, Sulawesi Selatan)," in Seminar Nasional LP2M UNM, 2019.

[3] A. Ismail and F. Umar, "Female Street Vendors In Domestic And Public Violence," in 1st International Conference on Social Sciences (ICSS 2018), 2018.

[4] A. Ismail and M. Mustadjar, "Local Knowledge As Consciousness To Avoid Primordial Sentiment," in $1 s t$ International Conference on Social Sciences (ICSS 2018), 2018.

[5] A. Ismail, "Environment Conservation toward Local Culture on Belief."

[6] M. Huberman and M. B. Miles, The qualitative researcher's companion. Sage, 2002.

[7] A. Anggito and J. Setiawan, Metodologi penelitian kualitatif. CV Jejak (Jejak Publisher), 2018.

[8] P. Sugiyono, "Metodologi penelitian kuantitatif kualitatif dan R\&D," Alpabeta, Bandung, 2011.

[9] A. Arisal, "Nilai-nilai Budaya dalam Prosesiritual Mallangī Arajang pada Masyarakat Bugis Soppeng Sulawesi Selatan," in Seminar Nasional LP2M UNM, 2017, vol. 2, no. 1 .

[10] A. Ahmadin, "Nama Diri dan Identitas Sosial Orang Selayar (Suatu Kajian Sosiologi)," in Seminar Nasional LP2M UNM, 2017, vol. 2, no. 1.

[11] A. Muhiddin, "Studi Kesiapan Desa Menerima Dana Desa di Kabupaten Gowa," in Seminar Nasional LP2M $U N M, 2017$, vol. 2, no. 1.

[12] K. Crenshaw, "Demarginalizing the intersection of race and sex: A black feminist critique of antidiscrimination doctrine, feminist theory and antiracist politics," $u$. Chi. Leg. f., p. 139, 1989.

[13] B. Hooks, Feminist theory: From margin to center. Pluto Press, 2000. 